Handbuch Medien der Literatur 



\section{Handbuch Medien der Literatur}

Herausgegeben von

Natalie Binczek · Till Dembeck · Jörgen Schäfer 
ISBN 978-3-11-020493-3

e-ISBN 978-3-11-029557-3

\section{Library of Congress Cataloging-in-Publication Data}

A CIP catalog record for this book has been applied for at the Library of Congress.

\section{Bibliografische Information der Deutschen Nationalbibliothek}

Die Deutsche Nationalbibliothek verzeichnet diese Publikation in der Deutschen Nationalbibliografie; detaillierte bibliografische Angaben sind im Internet über http://dnb.dnb.de abrufbar.

(C) 2013 Walter de Gruyter GmbH, Berlin/Boston

Satz: Dörlemann Satz GmbH \& Co. KG, Lemförde

Druck und Bindung: Hubert \& Co. GmbH \& Co. KG, Göttingen

@ Gedruckt auf säurefreiem Papier

Printed in Germany

www.degruyter.com 